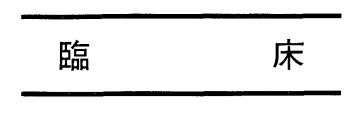

\title{
小脳橋角部類上皮腫例
}

\author{
伊藤 弘美・横田＼cjkstart明・馬場 駿吉*
}

\section{Epidermoid Cyst of the Cerebello-Pontine-Angle; A Case Report}

\author{
Hiromi Ito and Akira Yokota \\ (Nagoya Municipal Higashi Shimin Hospital) \\ Shunkichi Baba \\ (Nagoya City University)
}

Intracranial epidermoid cyst is a relatively rare disease accounting for $1.1 \%$ of all brain tumors and $3.0 \%$ of cerebello-pontine-angle (GPA) tumors. The neurological symptoms are similar to those caused by other CPA tumors, since the origin is anatomical. The clinical symptoms appear very slowly due to the embryologic origin, and few of the symptoms are typical. Consequently, accurate diagnosis is often difficult, and proper treatment is usually not possible.

We treated one patient with epidermoid cyst of the GPA, a 49-year-old woman with the chief complaint of glossopharyngeal neuralgia. She also had hearing loss and paresthesia of the trigeminal nerve.

CT \& MRI were very useful in the diagnosis.

Key words : tumor of the cerebello-pontine-angle, epidermoid cyst, glossopharyngeal neuralgia, magnetic resonance imaging (MRI)

はじめに

頭蓋内の類上皮腫は，全脳腫瘍の $1.1 \%$ ，小 脳橋角部（以下 CPA と略す）の3.3\%を占め る稀な疾患である ${ }^{1)}$

従来, 真珠腫 (pearly tumor or cholesteatoma) と呼ばれ, 胎生 3 週頃の神経管閉鎖時 期に迷入した上皮組織から発生する腫瘍 ${ }^{2)}$ 之考 えられ，緩徐な発育のため，臨床症状の発現に は，かなりの期間を要する.
本症については, King ${ }^{3)}$, Rand ら"光による詳 細な報告があるが，本邦では，1906年の山村の 報告以後，文献上に時々散見されており ${ }^{5)}$ ，三 叉神経痛を主訴とした小脳橋角部類上皮腫の報 告(6) 8) 屯時に見られるようになった。しかし， 舌咽神経痛を主訴とした報告は，ほとんどな $\left(^{9)}\right.$ ，我々は，舌咽神経痛を主訴に三叉神経知 覚麻痄・難聴を合併した小脳橋角部類上皮腫の 一例を経験したので，画像診断の有用性につい 
て述べるとともに文献的考察を加えて報告する．

$$
\text { 症例 }
$$

患者：49才，女性.

職業：縫製業.

既往歷及び家族歴：特記すべきことなし。

現病歴：昭和 50 年頃より, 左耳鳴・難聴に気 付くもミシン音のためと思い，放置したが，昭 和51年近医に 6 力月通院した。 しかし，効果な く再放置となる。以後，めまいを感じること 屯時々あった。昭和 63 年 7 月初め左舌痛出現 (図 1)，徐々に増強してきたので昭和63年 7 月 11日当科初診となった。

検查所見 :

1) 神経耳科的検査

聴力検査（図 2) では，4 分法による平均聴 カレベル $58.5 \mathrm{~dB}$ の左混合性難聴を認める.

平衡機能検查 (図 3) では, 左半規管機能の 高度低下を認めたが，眼振を含め, ETT, OKP， 立ち直り検査ともに異常を認めず，小脳症状む 特に認められなかった。

$\mathrm{ABR}$ (図 4) では，クリック音による両側 90 $\mathrm{dB}$ 刺激左誘導で， I 波の振幅の低下が，見ら れたが，潜時の遅れはなかった。左側 $90 \mathrm{~dB}$ 刺激左誘導では，無反応であった。

2 ) 画像検査

X線写真上, 内耳道の拡大は認めず（図 5 ）, 頭部正面単純写真（図 6) で, 両側茎状突起の 延長を認めた。特に右側茎状突起の化骨が，顕 著であった。

単純 CT で，左 CPA に広がる辺縁不整な low density area を認めたが, enhance CT によ る造影効果は，見られなかった（図7）。

MRI（図 8) では，左 CPA で low intensity, T2 強調画像で high intensity な mass を認めた。しかし，周囲の䯣液信号に 比へ, $\mathrm{T} 1 \cdot \mathrm{T} 2$ 強調画像ともに high intensity で あった. T1 強調画像の矢状断・前額断（図 9) では，橋底部，小脳を low intensity な mass が 占拠し，脳幹部・小脳扁桃の萎縮が見られた.

VAG（図10）では, 後下小脳動脈がやや正中
へ偏位するも，特に tumor stain は認められな かった。

以上より，小脳橋角部類上皮腫の術前診断の 屯とに，昭和63年 9 月 30 日後頭下開頭で，手術 を施行した，腫痬は，第 V脳神経から第 $\mathrm{X} ・ \mathrm{X}$

・XI脳神経までの範囲で存在し, pearly tumor と形容される如く真珠様光沢を示すクリーム状 を呈していた。硬膜直下の手術野（図11）では， 舌咽神経を含むlower cranial nerve と小脳との
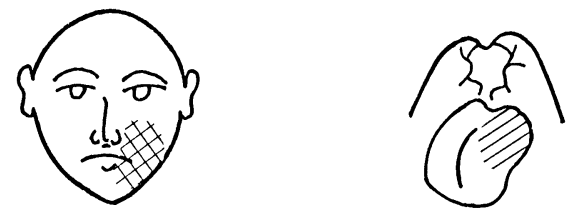

（劝部ーしびれ部位，〔部一痛み部位）

図 1 初診時所見

Audiogran

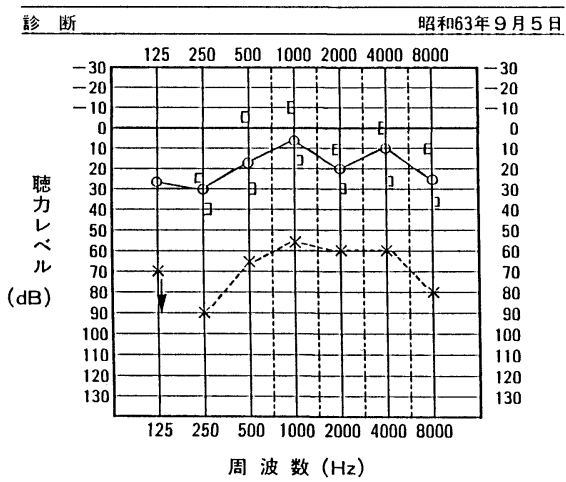

図 2 聴力検査 左混合性難聴を示す.

Vestibular Function

$\begin{array}{lll}\text { Romberg } & \text { Test } & \text { O.K. } \\ \text { Mann } & \text { Test } & \text { O.K. }\end{array}$
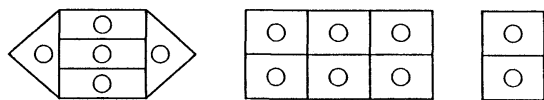

ETT Smooth

OKP 左右差なし

$\begin{array}{rr}\text { Caloric Test } \\ \underset{\left(20^{\circ} \mathrm{C} \mathrm{20cc}\right)}{r} & 112 \mathrm{sec} \\ \ell & 12 \mathrm{sec}\end{array}$

図 3 平衡機能検査 左半規管機能の高度低下を認める. 
耳鼻臨床 $83: 1$
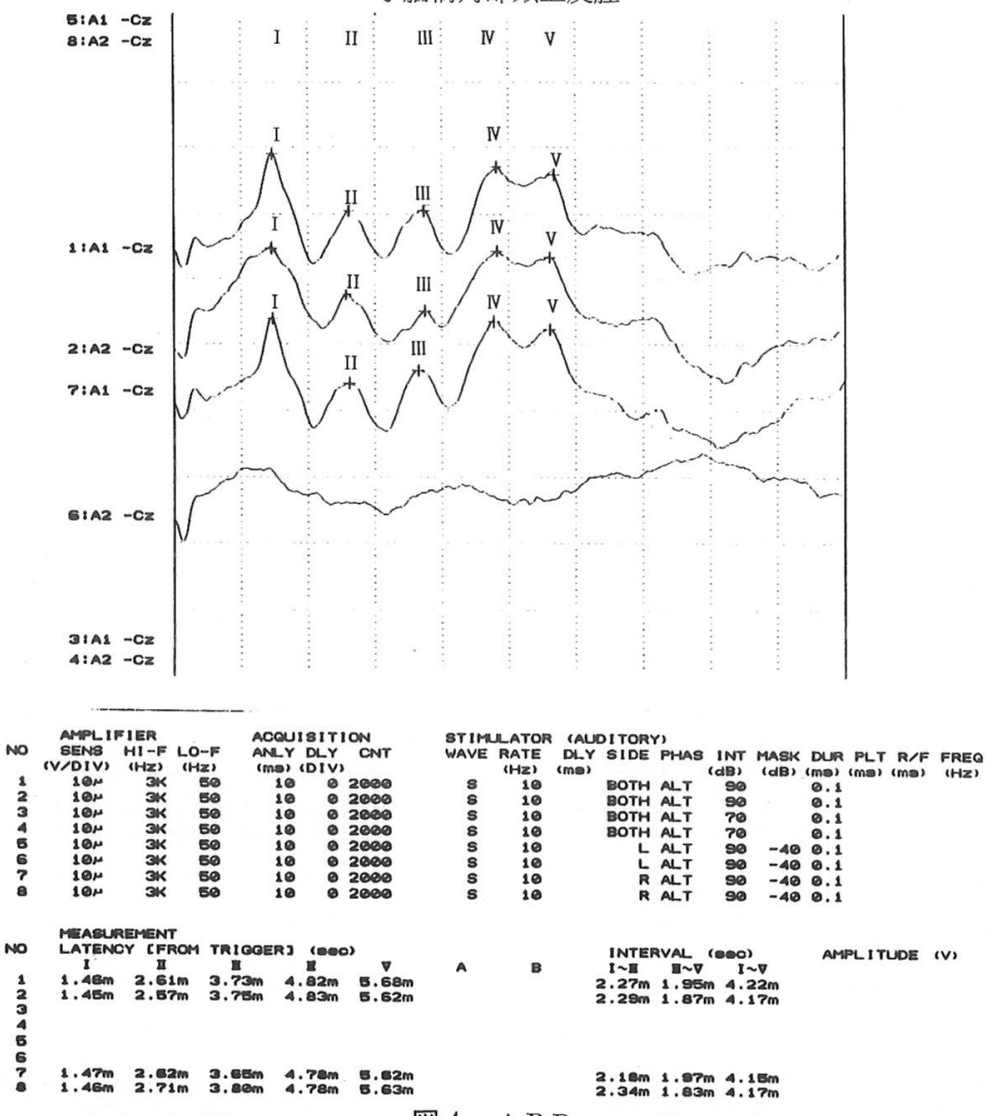

図 4 A B R

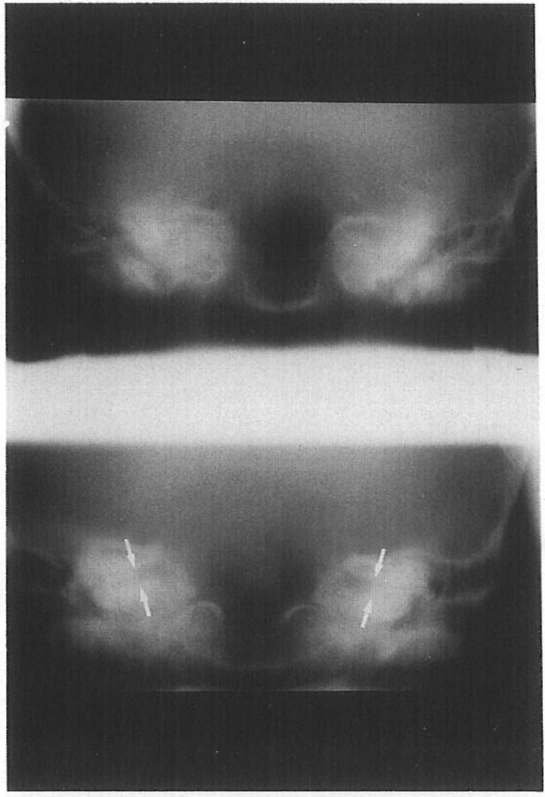

図 5 内耳道断層写真 矢印は，内耳道を示す.

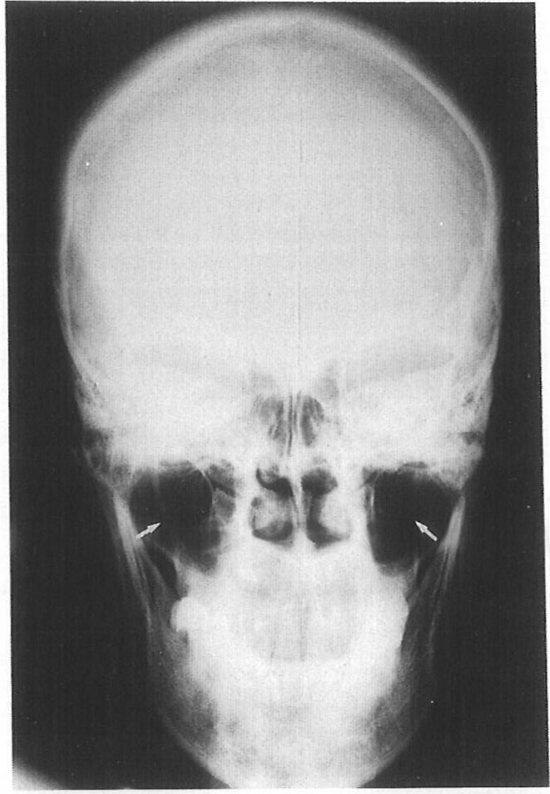

図 6 頭部正面単純写真 茎状突起 (矢印) の延長孛認める. 


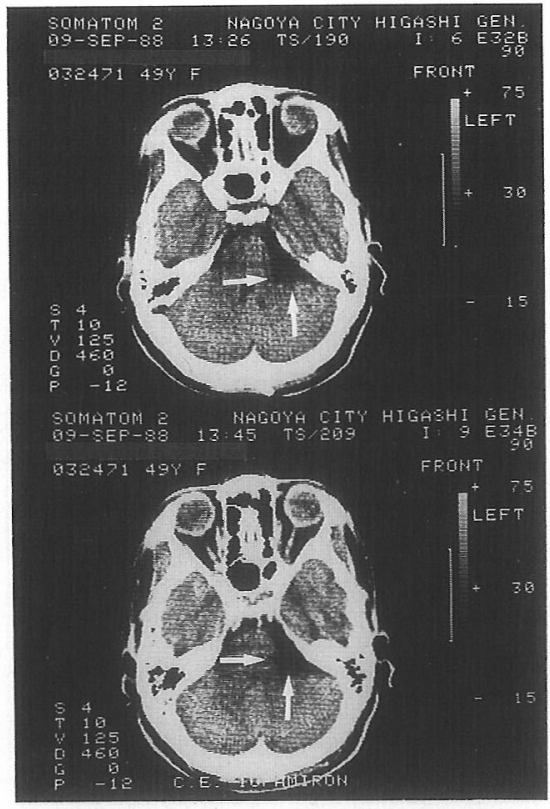

図 $7 \mathrm{CT}$

上段: 単純 $\mathrm{CT}$ 下段: 造影 $\mathrm{CT}$ 造影効果を認ぬない.

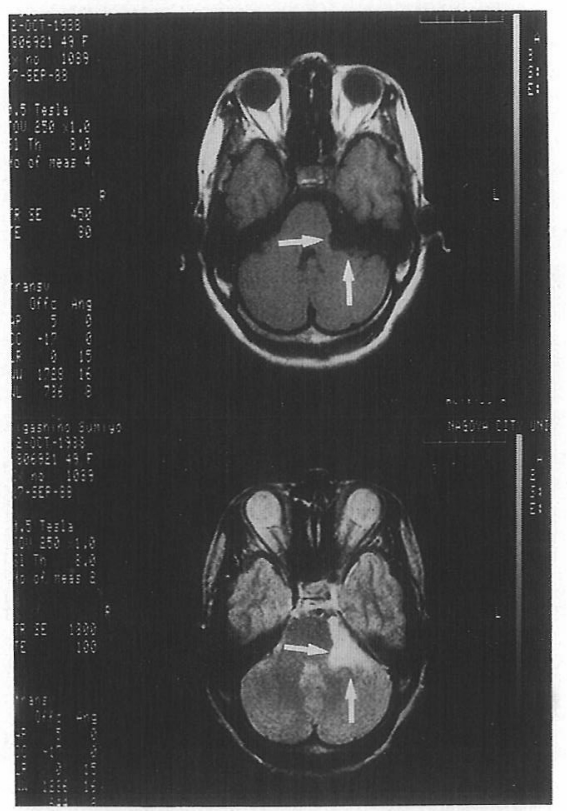

図 8 MR I（水平断） 上段： T 1 強調画像 下段： T 2 強調画像 矢印は, 腫瘍の進展範囲を示す.

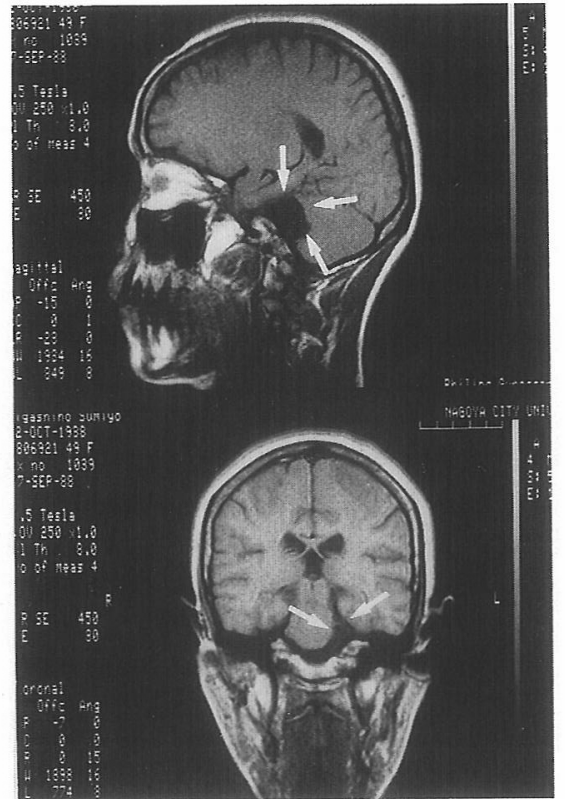

図 9 MR I （T 1 強調画像） 上段 : 矢状断 下段 : 前額断 腫瑒は，小脳扁桃，橋底部を占拠する。

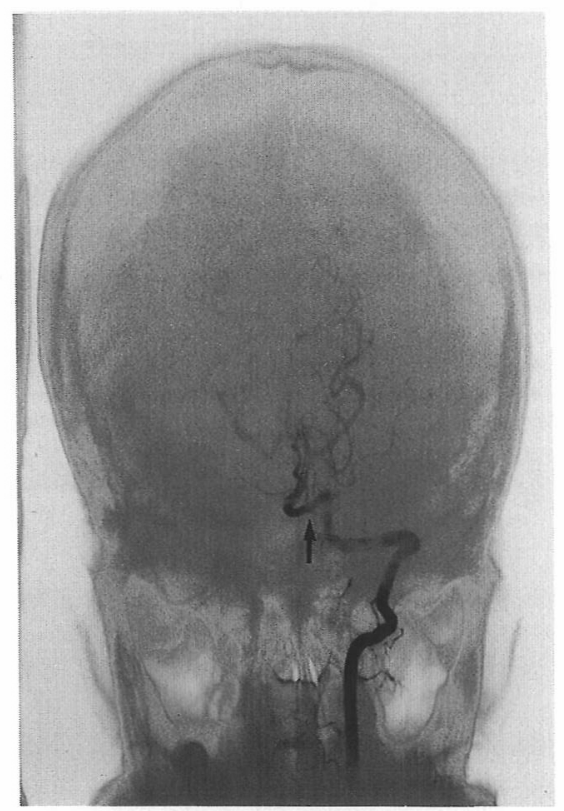

図10 VAG

後下小脳動脈 (矢印) が, やや正中に偏位する. 
間に，白色クリーム状の腫瘍が充満していた。 腫瘍を piece by piece に除去していくと第壮脳 神経は，全周にわたり腫瘍に取り囲まれており， 萎縮・発赤が著明であった（図12）。しかし第 $V$ 及び第 IX脳神経には，肉眼的な変化は見られ なかった。

病理組織所見（図13）は，真皮組織の 3 構造， すなわち表皮胚芽層・顆粒層・角質層からなる 被膜に包まれた角質組織を示す類上皮腫 ${ }^{10}$ であ った。

患者は，術後約 1 カ月で退院した。主訴であ る舌痛と三叉神経知覚麻痺は，全く消失した。 しかし難聴は，術前とほぼ同じであった。

\section{考察}

類上皮腫は，その発生学上，上皮細胞加ら脱 落したコレステロールを含む keratin debris を内包しながら，非常に緩慢な発育をするため， 臨床症状を呈する大きさになるまでにかなりの 時間を要する ${ }^{2}$ 。また，小脳橋角部類上皮腫は，
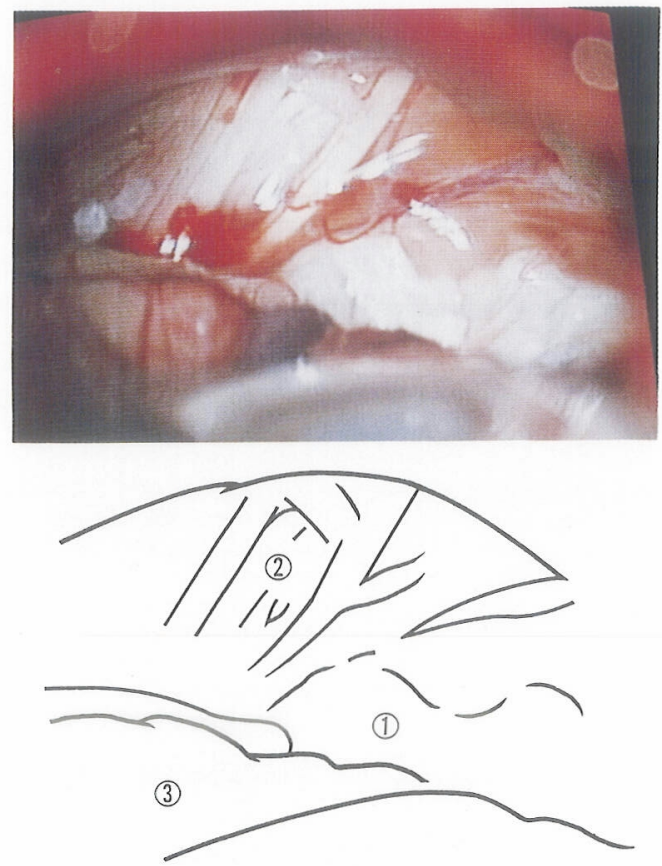

図11 硬膜直下の手術所見
(1) 類上皮腫
(2) lower cranial nerves
(3) 小脸

その解剖学上，小脳及び脳幹を中心とした周囲 の中枢神経系に影響を及ぼし，種々の脳神経症

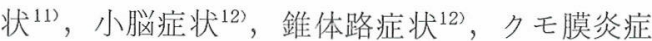

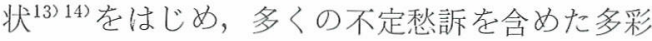
な臨床症状を示す，そのため，多発性硬化症。
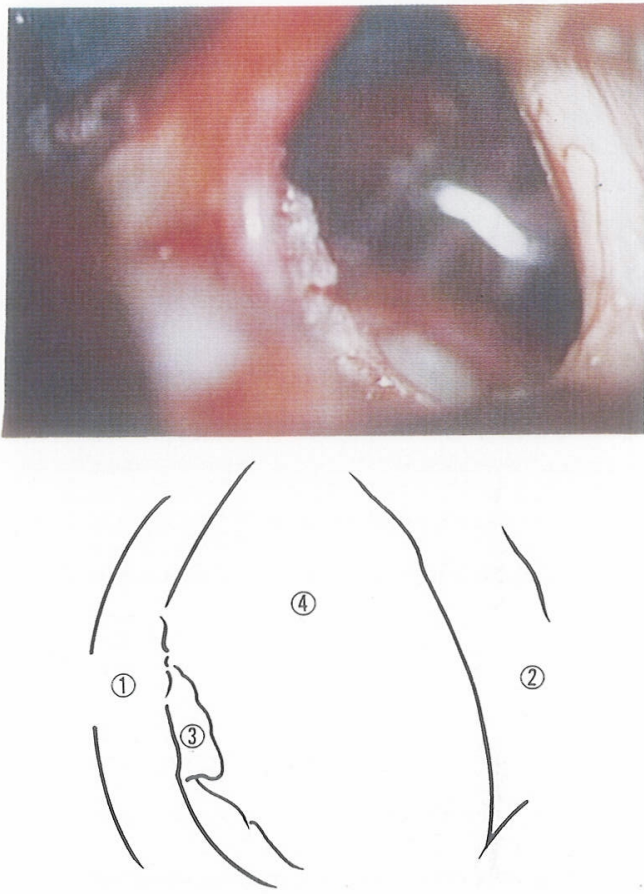

図12腫瘍をほぼ摘出した後の手術所見

(1) 第VIII脳神経

(2) 第 V 脳神経

(3) 聴神経を取り巻いていた腫湯の一部

(4) 脳幹

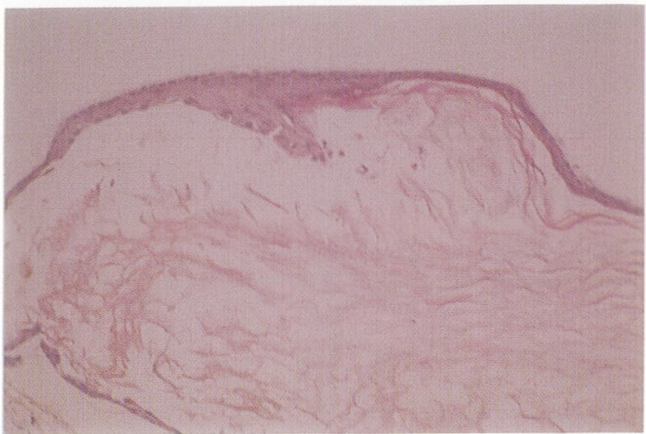

図13 病理組織所見

真皮組織の被膜に囲まれた角質物よりなる。 
脊䯣小脳変性症・特発性三叉神経痛など，誤っ た診断を受けている場合がたびたびある。

我々の症例屯, 初発症状は難聴・耳鳴という 第VII脳神経症状であったが，縫製業という職業 柄, 本人もあまり難聴を気にせず, 近医での適 切な治療を受けないまま放置されてきた。その 間に腫瘍は，第 $\mathrm{V} ・$ 第 $I X$ 脳神経周囲まで発育し， それらの神経への圧迫により, 三叉神経知覚麻 瘦・舌咽神経痛が発現するに至ったと思われる。

いわゆる tic douloureuxは，狭義には，三叉 神経痛を意味するあのであるが，広義には，舌 咽神経痛も含まれ, 舌咽神経痛の発症率は, 三叉神経痛のそれの $1 \%$ 程度 ${ }^{15)}$ である。 三叉 神経痛における vascular compression 説は, Jannetta の三叉神経減圧術 ${ }^{16)}$ により証明され ているが，一部には，小脳橋角部腫瘍がその原 因(6) とななっているともある.

小脳症状は, Obrador ら ${ }^{12)}$ の報告によると小 脳橋角部類上皮腫16例中の 1 例に見られたのみ であり，決して多いものではない。一般に小脳 症状の発現は, 小脳の萎縮に比し, 軽いとされ ている2.. 我々の症例も, MRI 上, 左小脳扁桃 にかなりの萎縮は見られるにもかかわらず，小 脳症状を認めなかった。

小脳橋角部類上皮腫の診断は，その発生学上 及び解剖学上の理由により, 臨床症状からのみ では，困難なととが多い。しかし，今日の画像 診断，乙とに CT や MRI の進歩はめざましく, 本症をはじめとする頭蓋内の種々の腫瘍性疾患 の診断は，極めて容易かつ確実化されてきてい る. 今回, 左混合性難聴は, 認められるものの, 内耳道の拡大はなく，また難聴の訴えよりも舌 痛を強く訴えたため聴神経腫瘍を除外し, 茎状 突起過長症あるいは, 特発性舌咽神経痛として の治療を先行させるとととなった。しかし，鎮 痛剂やテグレトールを中心とした保存的治療で の軽快が見られないため，さらに CT 検査を施 行したところ CPA に広がる辺縁不規則な low density area が認められ, enhance による造影効 果を受けないととがわかった。すなわち，この
時点で小脳橋角部類上皮腫という診断を確実に することが，できたわけである.

$\mathrm{CT} \operatorname{scan}$ 導入後，乙の腫瘍の報告はときどき 見られるようになってきている，すなわち， Timir $ら^{17)}$, Chambers ら ${ }^{18)} は$, epidermoid cyst の CT 像は，均等な low density が特徵 であるととを述べ, Davis ${ }^{19)}$ は, 造影 CTで enhance されないことを述べている，また，長 島ら ${ }^{20)}$ は, 過去の文献から39例の頭蓋内類上皮 腫の CT 所見を検討し，36例の硬膜内類上皮腫 全例が，造影されず，硬膜外類上皮腫 3 例すべ てに造影効果を見られたてとを述べている。一 般に low density で，造影効果のないことが, CT 上の特徴であるが, 最近 high density を示

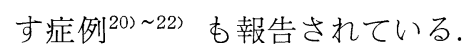

本症例では，施行しなかったが，脳春髄腔に 造影剤を注入する metrizamide CT むこの腫瘍 に特徵的な所見 293 23) 24) を示すとされている. すなわち, cauliflower 状 honeycomb 状 sponge 様と形容されるように CT 上, low density 内が, 不規則に造影されるという。

血管撮影では，乙の腫瘍に特徽的な所見は， 少ない. その理由のひとつには，腫瘍の被膜が 非常に薄く，かつ血管成分にそしいため ${ }^{25}$ であ り，あうひとつは，腫瘍が間隙を埋める形で発 育するため，特徴的な形を示さないととにある。

MRI は CT と比較し被爆の危険もなく，方 向の選択に制限を受けず，周囲組織から受ける アーチファクト屯少ない. また, 頭蓋内の微細 な構造まで読み取ることができ, 腫瘍の進展範 囲屯把握しやすい。しかし，その普及率は，ま だ低く，検査者の技術や機種の違いにより，で きあがったフィルムに差を生じているのが現状 である.

しかし，MRI を利用した報告屯近年相次ぎ， David ら ${ }^{26)}$ は，腫瘍の信号強度については， $\mathrm{T} 1$ 強調画像では，脳実質と脳脊䯣液との中間 信号を示し, T2 強調画像では, 脳実質より高信 号を示すととを述べている. Lindell ら ${ }^{27)}$ は，聴 神経腫瘍, 髄膜腫, 膠芽腫, く屯膜囊胞など 
他の CPA 腫瘍との鑑別を述べている。 また Jeffrey ${ }^{28)}$ は, CT と MRI との有用性の比較を 検討し，MRI は，CT に較べ，その画像が， 手術操作に，より多くの情報を提供するととを 述べている.

我々の症例屯諸家 ${ }^{26) 27}$ 29) 30) の報告同様, T1 強 調画像で low intensity を示し, T2 強調画像で high intensity な mass を認めた。今後 MRI を利用した症例の増加及び診断技術の向上によ り，囊胞成分の違い ${ }^{22}$ が信号強度に与える影響 についての研究も一層進展するむのと思われる.

また，一部亜性化を来した症例 ${ }^{31132)}$ ああるて とを考慮すると本腫瘍に沶いても早期の発見之 治療が必要とされるととは，言うまでもないと とである。

\section{まとめ}

舌咽神経痛を主訴に三平神経知覚麻痺, 難聴 を合併した49才女性の小脳橋角部類上皮腫の一 例を報告した。

この腫瘍の診断には, CT や MRI などの画像 診断がきわめて有効であり，CT では，造影効 果を示さない低吸収像が，また，MRI では， $\mathrm{T} 1$ 強調画像で low intensity, T2 強調画像で high intensity を示すのが，一般的特徽である.

稿を終えるにあたり，適切な御指導をいただいた 当院脳外科部長高木卓爾先生，水野志郎先生に厚く感 謝致します，尚，本論文の要旨は，第90回日耳鼻総会 （大阪市）および第 2 回日本口腔咽頭学会総会（大阪） で，口演した。

\section{参考文献}

1）脳腫瘍全国統計委員会：脳腫瘍 全国 集計調査報 Vol 5. 1969～1978頁，厚生省，東京，1984．

2 ）布施孝久, 高木卓爾, 大野正弘, 他：小脳萎縮を 伴った小脳橋角部類上皮腫の一例. 脳神経外科 $17: 673 \sim 677,1989$.

3) King JEJ : Extradural diploic and intradural epidermoid tumors. Ann Surg 109:649 688, 1939.

4) Rand CW and Reeves DL : Dermoid and epidermoid tumors (cholesteatomas) of the central nervous system, report of 23 cases. Arch Surg $46: 350 \sim 376,1943$.

5 ) 牧豊, 堀江 武：頭蓋内 epidermoid につい て. 脳と神経 $16: 321 \sim 330,1964$.

6 ）上田 孝, 点屋朝和, 木下和夫, 他: 三叉神経痛 を呈した小脳橋角部 epidermoid cyst の 1 症例. Neurol Med Chir (Tokyo) $23:$ 375 380, 1983.

7 ）富永正夫，角田 茂，榊 寿右，他：典型的三叉 神経痛で発症した小脳橋角部 epidermoid cyst. 奈良医誌 $37 ： 313 \sim 319 ， 1986$.

8 ）緒方政則，重松昭生，田中孝夫，他：Epidermoid cyst による三叉神経痛の症例。ペインクリニック $6: 179 \sim 183,1985$.

9 ）長谷川健，若松弘一，藤井登志春，他：MCTC で陽性に造影された小脳橋角部類上皮腫. 臨放 $30: 479 \sim 500,1985$.

10）太田富雄，西村周郎：脳神経外科学. $430 \sim 433$ 頁，金芳堂，東京，1986。

11) Joseph TL, Jack MK, Johon LK, et al : Epidermoidomas of the cerebellopontine angle and temporal bone, CT and MR aspects. Radiology $157:$ 361 366, 1985.

12) Obrador $\mathrm{S}$ and Loper-zafra JJ : Clinical features of the epidermoid of basal cisterns of the brain. J Neurol Psychiatry 32: 450 454, 1969.

13) Kendall $B$ and Symon L : Investigation of patients presenting with cerebellopontine angle syndromes. Neuroradiology $13: 65 \sim 84,1977$.

14) New PF and Arnow S : Attenuation measurement of whole blood and blood fractions in computed tomography. Radiology 121:635 640, 1976.

15）野村恭也，石井哲夫編：耳鼻咽喉科診断治療大 系. 29頁. 講談社, 東京, 1986 。

16) Janetta PJ : Vascular decompression in trigeminal neuralgia. The Cranial Nerves. pp 331 340, Springer-Verlag, Berlin, 1981.

17) Timir B and Martin RK : Intracranial epidermoid tumor; discussion of four cases. South Med J $70: 6 ; 726 \sim 727,1977$.

18) Chambers AA, Lukin RR and Tomisck TA: Cranial epidermoid tumors; diagnosis by computed tomography. Neurosurgery $1: 276 \sim 280$, 1977. 
19) Davis KR, Roberson GH, Toveras JM, et al : Diagnosis of epidermoid tumor by computed tomography. Radiology $119:$ 347 353, 1976.

20）長島親男, 坂口 新, 高浜素秀, 他：CT で diffuse high density と一過性反復性動摇視を示し た小脳橋角部類上皮腫. 脳神経外科 $9: 851 \sim$ 859, 1981.

21) Nagashima C, Takahama M, Sakaguchi A,et al: Dense cerebellopontine epidermoid cyst. Surg Neurol $17: 172 \sim 177,1982$.

22）伊藤義広，賀来素之，児玉万典，他：CT scan に て High Density を示す Epidermoid とその化学 組成. 脳神経外科 8：7；645 648，1980.

23) Jack MF, Kenneth L, Fashid $T$, et al : Epidermoid tumor of the cerebellopontine angle; diagnostic value of computed tomographic metrizamide cisternography. Neurosurgery $9:$ 179 182, 1981.

24）鈴木千尋，長島親男：小脳橋角部 Epidermoid Cyst. 埼玉医科大学雑誌 11：1；35～42，1984.

25) Barbara SK and Gerald W : Radiologic evaluation of epidermoid cyst. J Natl Med Assoc $79: 2 ; 209 \sim 212,1987$

26) David JS, Gary JDF, Thomas S, et al : MR imaging of primary epidermoid tumor. J Comput Assist Tomogr 12: 3; 438 440, 1988.

27) Lindell RG, Charles GJ, Patrick AT, et al :
Cerebellopontine angle petromastoid mass lesions; comparative study of diagnosis with MR imaging and CT. Radiology $162: 513 \sim 520$, 1987.

28) Jeffrey JO, David WB, Stephen CC, et al : Comparative evaluation of intracranial epidermoid tumors with computed tomography and magnetic resonance imaging. Neurosurgery 21 : 357 360, 1987.

29) Michael SR, Peter YP, George W, et al : Magnetic resonance imaging of intracranial epidermoids; report of two cases. J Can Assoc Radiol 38 : 283 288, 1987.

30) Vion-Dury J, Vincentelli F, Jiddane M, et al : MR imaging of epidermoid cysts. Neuroradiology $29: 333 \sim 338,1987$.

31）松野 彰, 渋井壮一郎, 落合慈之, 他：小脳橋角 部の悪性類上皮腫の一例. 脳神経外科 15:851 858, 1987.

32）石松俊之, 横山繁生, 中山 㛜, 他 : 右小脳橋角 部の類表皮囊胞より発生した扁平上皮癌の一剖検 例. 病理と臨床 $6: 89 \sim 93,1988$.

(原稿受付 : 平成元年 6 月 20 日 原稿採択 : 平成元年 7 月 10 日 別刷請求先 : 伊藤弘美

干464 名古屋市千種区若水町1-2-23 名古屋市立東市民病院耳鼻咽喉科 